Agnes Máté

https://orcid.org/oooo-0002-I827-8583

Department of Classical Philology and Neo-Latin Studies

University of Szeged (Hungary)

\title{
Griseldis Báthory, the Disobedient Bride or the Unsuccessful Taming of a Heretic Shrew*
}

Celem artykułu jest prześledzenie początkowej fazy małżeństwa Jana Zamoyskiego z Gryzeldą Batory, przyjrzenie się kwestii zmiany nazwiska panny młodej oraz problemów wynikających z różnych wyznań małżonków. Wbrew planom króla Stefana Batorego i hetmana Zamoyskiego Gryzelda nie przeszła na katolicyzm. Wychowanie przez protestancką matkę i babkę wzięło górę nad politycznymi interesami katolickich członków jej rodziny.

The article aims to examine the initial phase of the marriage of Jan Zamoyski with Griseldis Bathory, the issue of change of the bride's name, and the problems caused by the newlyweds' difference of faith. Despite the plans of king Stephen and hetman Zamoyski, the young bride did not become a Catholic. Her upbringing by her Protestant mother and grandmother overrode the political interests of her Catholic male relatives.

Słowa kluczowe: Gryzelda Batory, Jan Zamoyski, ślub, epitalamia (pieśni weselne), zmiana imienia, różnice wyznaniowe, role kobiece K e y w o r d s: Griseldis Báthory, Jan Zamoyski, wedding, epithalamia, change of Christian name, confessional differences, female roles

* The paper was written as part of the project NKFIH PD128227 Royal and Aristocratic Neo-Latin Epithalamia Production in Early Modern Hungary, and its translation was financed by the Wacław Felczak Foundation. 
Prologue

In the days around 12 June 1583, the most sumptuous celebration of Polish King Stephen Báthory's reign was held in Cracow: the triumphal festivities after the successful Livonian campaign, ${ }^{1}$ concluded with the king marrying his fourteen-year-old niece Griseldis Báthory (1569-1590) to Polish hetman Jan Zamoyski. In this paper, I analyse the Latin literary sources referring to the wedding and the exchange of letters between Cracow and Rome from April to October 1583. I focus on Griseldis Báthory's characterisation and her settling in her new homeland, contrasting the expectations about her with the actual fulfilment of her roles both as niece to the Catholic king and wife to the Catholic chancellor of Poland. Based on the documents, it can be concluded about the promising dynastic marriage that even important political interests could not override the moral dilemmas caused by the religious views of the Catholic groom and the Protestant bride. The bride was given a new name in Poland, Griseldis, a symbol of outstanding patience and obedience, introduced to the European collective imagery by the works of Giovanni Boccaccio and Francesco Petrarca. In my opinion, however, the name that stuck with the Transylvanian bride for the rest of her life served as an eternal memento of the unsuccessful attempt to convert her: she became Griseldis in name, but in her faith, she remained Protestant, i.e. disobedient to her Catholic male relatives till the end.

The literature traditionally links five Latin-language publications to the marriage of Chancellor Zamoyski and Griseldis. Jan Kochanowski's works Epinicion ${ }^{2}$ and Epithalamion, ${ }^{3}$ Mattheus Priscovius' Gratulatio, ${ }^{4}$ the report to Elector of Brandenburg Georg Friedrich

1 J. Kowalczyk, "Mars i Parys. Uroczystości tryumfalne i weselne w Krakowie w 1583 r.", in: J. Kowalczyk, W kręgu kultury dworu Jana Zamoyskiego (Lublin, 1980), pp. 103-159, 290-298. I. Horn, "Báthory István uralkodói portréja” [Stephen Báthory's portrait as a sovereign], in: Politikai propaganda és reprezentáció a kora újkorban [Political propaganda and representation in early modernity], ed. N. G. Etényi, I. Horn (Budapest, 2008), pp. 363-400.

2 I. Cochanovii, Ad Stephanum Bathoreum Regem Poloniae inclytum Moscho debellato, et Livonie recuperata. Epinicion (Cracoviae, 1583).

3 I. Cochanovii, In Nuptias Illustrium Ioan de Zamoscio, R. P. Cancellarii, et exercitum Praefecti: Ac Grisledis Bathorrheae Christophori Transilvaniae principis et Sereniss. Stephani Poloniae regis fratruis, filiae. Epithalamion (Cracoviae, 12 June, 1583).

${ }^{4}$ Ad Illusstrissimum D. Ioannem Zamoiscium R. P. Cancellarium. Et Exercituum Imperatorem. De Nuptiis cum Illustriss. Domina D. Griselide Bathorrea, Translyvaniae 
on the wedding celebrations, ${ }^{5}$ and the poem Istula sive gratulatio by Valentinus Schreckius, the schoolmaster of Schola Mariana, the school operating next to St Mary's church in Gdańsk. ${ }^{6}$ From these, Kochanowski's Epinicion, which is essentially a panegyric on King Stephen Báthory's military accomplishments during the Livonian War, only refers to Zamoyski and Griseldis' marriage in its dedication. Even the new critical edition of Kochanowski's Epithalamion ${ }^{7}$ makes almost no mention of the couple in the poem. The Epithalamion is primarily evaluated based on its poetic form since its triadic structure (strophe, antistrophe, epode) draws on the ode poetry of Pindar and Catullus. In my opinion, Priscovius' Gratulatio can be considered a political declaration of the Polish nobility, discussing the political role of a king in an elective monarchy and the limitations of royal power, in the form of a speech dedicated to the Polish hetman and his third wife. The report to the elector of Brandenburg is an eyewitness chronicle of, among others, scenes displayed in an impressive parade ranging from the procession of prisoners of war from the completed Livonian War to the triumph of Venus, thus expressing the victory of Amor and Venus over Mars. ${ }^{8}$ In turn, Schreckius' poem recites Zamoyski's family history going back several centuries, using the image of the river god Vistula, which crosses the most important Polish cities. Schreckius also briefly sketches the young bride's background, finally expressing his best wishes to the young couple.

Since all five works were created in Poland, it is not surprising that they focus on the Polish events, as well as the powerful groom.

nata principe, Serenissimi Poloniae Regis Stephani primi, fratris filia, contractis. Idibusque Iunii celebratis. Cracoviae. Matthei Piscorevii Gratulatio (Cracoviae, 1583) (hereinafter cited as Piscorevius, Gratulatio).

5 De Nuptiis Illustrium Ioan. De Zamoscio R. P. Cancellarii execitt. Praefecti: Ac Griseldis Bathorreae, Christophori Transilvaniae principis, et Sereniss. Stephani Poloniae Regis fratris filiae: Ad Illustrissimum Principem Georgium Fridericum Marchionem Brandenburgen. in Prussia Ducem R. H. S. R. Epistola (Cracoviae, 1583). The works listed so far were also mentioned in passing in: J. Nowak-Dłużewski, Okolicznościowa poezja polityczna w Polsce. Pierwsi królowie elekcyjni (Warszawa, 1969), pp. 176-197, here: 190-191.

6 V. Schreckius, Istula sive gratulatio Ad Illustrem magnificum et generosum Dominum Ioannem Samoiscium de Zamoiscze: Inclyti Regni Poloniae Capitaneum generalem et Cancellarium etc. (Gdańsk, 1583).

7 J. Kochanowski, Carmina latina, Pars III. Commentarius, fecit Z. Głombiowska (Gdańsk, 2013), pp. 233-251.

8 Horn, “Báthory István”, p. 392. 
Something similar happened fifty years earlier, when Polish Princess Isabella Jagiellon was preparing to get married in Hungary. The authors in the Polish king's service all concentrated on Isabella, while only one humanist, Antal Verancsics, who was in the Hungarian king's service, described the events from King I John Szapolyai's point of view. ${ }^{9}$ In the texts prepared for the Zamoyski-Báthory wedding, the bride receives less attention for two reasons. On the one hand, neo-Latin epithalamia ${ }^{10}$ reflect the traditional perception of women, i.e. that the woman primarily brings her chastity, physical beauty, and spiritual piety to the marriage. On the other hand, in Griseldis Báthory's case, her family's good reputation, connections, and wealth are also added to the picture. However, the authors do not need to waste too many words on these characteristics since the bride is the daughter of the ruling Polish king's brother, which is enough guarantee for a good marriage in itself. Consequently, Griseldis Báthory's figure is overshadowed almost in its entirety by commonplaces and the fame of her family. Thus, in epithalamia in general, as well as in this specific case, the man is an individual, while the woman is barely more than her name. However, in Griseldis Báthory's case, her name leads us to the first act of the moral and matrimonial drama mentioned in the introduction.

Act One. Name Change: Krisztina Becomes $\mathrm{Griseld}$ is

It was a tradition in different social strata in Hungary that daughters were given their mother's or grandmother's Christian name, or sometimes a combination of these two. ${ }^{11}$ The daughter of Kristóf Báthory (1530-1581) and Erzsébet Bocskai (c. 1550-1581) was originally named after her maternal grandmother, Krisztina Sulyok. From the

9 Á. Máté, "A Literary Image of Renaissance Queenship: the Marriage of Isabella Jagiellon", in: Isabella Jagiellon, Queen of Hungary (1539-1559). Studies, ed. Á. Máté, T. Oborni (Budapest, 2020), p. 44.

10 A. F. D'Elia, The Renaissance of Marriage in Fifteenth-Century Italy (Cambridge, MA - London, 2004), p. 28.

11 On the importance of female naming conventions in epithalamia, see: Á. Máté, "Névetimológia és növényhatározó egy 17. századi nászénekben: jókívánságok David Spillenberger lőcsei orvos és Susanna Regina Reuther esküvőjére (1569)” [Etymology of names and plant taxonomy in a seventeenth-century epithalamium: well-wishes for the wedding of Lőcse physician David Spillenberger and Susanna Regina Reuther (1569)], Antikvitás és Reneszánsz VI, no. 2 (2020), pp. 78-80. 
years preceding her marriage, we barely know any documents that mention the girl by name. Paragraph four of the peace draft to be concluded between Polish King Stephen Báthory and the Russian tsar in 1581 mentions her as the daughter of the Transylvanian prince, and it can be deduced from the modern edition of the text that the Griseldis name is only a later editorial insertion, not part of the authentic document. ${ }^{12}$ Similarly, the nuncio in Cracow makes no mention of her name when he writes to Rome about her father's death and reports that the Polish Queen Anna planned to bring the twelve-year-old girl to her court. ${ }^{13}$

We only know of one document in which the bride-to-be is mentioned by her name Krisztina Báthory. Before the long journey, one member of the bride's entourage setting out for Poland, magister curiae György Lencsés, together with his wife, made a will on 23 April 1583. In this document, Prince Zsigmond Báthory refers to him in the following way: "Georgius Lencsés magister curiae Christinae Báthory, sororis nostrae". ${ }^{14}$ Thus, for those at home, the girl is still Krisztina, while approximately two months later, in the publications prepared for her wedding, she is already called Griseldis in Poland. A few decades later, historian István Szamosközy, who was born in 1570 and so was roughly the same age as her, writes about this name change with particular disdain:

Griseldis is Kristóf Bátori's daughter. Kristóf Bátori's daughter, whom King Stephen later married to the Polish chancellor, was first christened Christina, and that was her name for a long time. But not liking this beautiful name, based on Blandrata's version, she was named Griseldis, which is quite unusual and unheard of among Hungarian names. Thus, such people as Kristóf Bátori and his wife allowed themselves to make fools of themselves and their child by an Italian. Because Christina is a name that is a hundred times more beautiful, named after Christ, and it is not like

12 "filia enim Illustrissimi principis Transsylvaniae (Griseldis) recte in matrimonium tunc collocari posset M. Ducis filio", I. A. Caligarii nuntii Apostolici in Polonia epistolae et acta 1578-1581, ed. L. Boratyński (Kraków, 1915; Monumenta Poloniae Vaticana, IV = hereinafter cited as MPV IV), no. 385, p. 680 (the name is italicised and in brackets in the edition).

13 "la Serenissima Regina piglierà appresso di sé la sorella fanciulla di 12 anni", MPV IV, no. 390, pp. 696-697.

14 Budapest, Magyar Tudományos Akadémia Könyvtár és Információs Központ, Kézirattár (Library and Information Centre of the Hungarian Academy of Sciences, Manuscripts Archive), Veress Endre-hagyaték (Endre Veress estate) (hereinafter cited as VE-h), MS 433, p. 23. 
Griseldis, which does not know where the original comes from and where it is headed. It may have been taken from the name Chrysa, which is the name of a whore in a comedy, or Blandrata formed it from the name Briseis, who was Achilles' whore in Homer. ${ }^{15}$

Based on this, it seems true that the daughter had been called Krisztina "for a long time", possibly until she left Transylvania or even until the day of her wedding. However, Szamosközy's assumption that the name Griseldis was invented by Italian physician and heterodox thinker Giorgio Biandrata indicates several preconceptions and possibly deliberate distortion on the historian's part. Biandrata indeed could have had something to do with the name. The Italian physician was born in Saluzzo, and the heroine Griseldis, whose patience and loyalty was brutally tested by her husband several times, was indeed the legendary marchioness of that city in Piedmont. ${ }^{16}$ As is well-known, the character of Griseldis was immortalised in Italian by the last novella of Giovanni Boccaccio's Decamerone (Dec. X, 10). However, the educated European audience was introduced to the story of the patient woman by Francesco Petrarca's Latin translation De insigni obedientia et fide uxoris (Seniles XVII, 3). ${ }^{17} \mathrm{By}$ Szamosközy's time, the Latin version had also been translated into Hungarian as a gift for the marriage of Polish Princess Isabella Jagiellon and King John I Szapolyai (1539), ${ }^{18}$ and published in 1574 in

15 Szamosközy István történeti maradványai: 1566-1603, IV. Vegyes feljegyzések [István Szamosközy's historical remainders: 1566-1603, IV. Mixed notes] (Pest, 1876-1880), p. 9. On anti-Báthory propaganda in Transylvania, see T. Kruppa, Tradició és propaganda keresztútján. Fejezetek Báthory Zsigmond udvarának kultúrájából [At the Crossroads of Tradition and Propaganda: Chapters on the Culture of the Court of Zsigmond Báthory] (Budapest, 2015), pp. 51-67.

16 The work of Hungarian historian Ferenc Forgách, Szamosközy’s contemporary, literally mentions the Italian physician's Piedmont origins twice: "Blandrata pedemontanus”, Ghymesi Forgách Ferenc magyar históriája 1540-1572 [The Hungarian history of Ferenc Ghymesi Forgách 1540-1572], ed. F. Majer, F. Toldy (Pest, 1866; Monumenta Hungariae Historica: Scriptores, 16), p. 30 and 70.

17 For the international dissemination of the story, including Central-Eastern Europe, see: Griselda, metamorfosi di un mito nella società europea. Atti del Convegno internazionale a 80 anni dalla nascita della Società per gli studi storici della provincia di Cuneo, Saluzzo, 23-24 April, 2009, ed. R. Comba et al. (Cuneo, 2011).

18 Gy. Komlóssy, "La storia di Griselda come regalo di nozze”, in: Griselda, metamorfosi, pp. 145-154. Á. Máté, "Il ruolo di 'capro espiatorio' delle regine, ovvero la favola Griselda come speculum reginae nella storia ungherese", Rivista di Studi Ungheresi 15 (2016), pp. 7-23. 
Debrecen and in 1580 in Kolozsvár (today's Cluj in Romania). Furthermore, just like Pál Istvánffy, who translated the Griseldis story into Hungarian, ${ }^{19}$ historian Szamosközy had also studied in Italy (1591-1593). If not still at home in Transylvania, in Padua at the latest, Szamosközy also must have become familiar with Griseldis' story, at least in Petrarca's Latin version. Petrarca's grave in nearby Arquà was a place of his cult and was regularly visited by Hungarian students. In light of these data, it is not easy to believe that Szamosközy did not know what female virtues the Griseldis name symbolised. In addition, since Giorgio Biandrata spent decades in Transylvania and died there, Szamosközy must have known that the physician was born in Saluzzo in Piedmont; thus, his confusion in connection with the name's origin does not ring true.

Furthermore, the etymology of the name offered by the Transylvanian historian is decidedly crude. According to Szamosközy's explanation, the Griseldis name comes either from Terence's comedy Andria or the Iliad, but it definitely means 'whore. ${ }^{20}$ In my opinion, the reason behind this interpretation could be Szamosközy's confessional aversion towards Giorgio Biandrata, whom he believed to have paved the way to anti-Trinitarism in Transylvania. ${ }^{21}$

However, Szamosközy's hypothesis concerning Biandrata's role could still have some element of truth. The Italian physician may not have been the mastermind behind Krisztina Báthory's new name, but he was in close contact both with Poland ${ }^{22}$ and with Chancellor

19 P. Ács, “Boccaccio Baranyában. Egy kivételes értelmiségi pálya a 16. század első felében: Istvánffy Pál” [Boccaccio in Baranya County. An Exceptional Intellectual Career in the First Half of the Sixteenth Century: Pál Istvánffy], in: "A magyar történet folytatója”. Tanulmányok Istvánffy Miklósról ["Who continued Hungarian History”: Essays on Miklós Istvánffy], ed. P. Ács, G. Tóth (Budapest, 2018), pp. 37-58.

20 The word 'whore' in Hungarian is transparent also for Polish readers, having only the ortographical difference of $\mathrm{v}-\mathrm{w}$ in comparison to the Polish word. "Talám az Chrysa névtűl vötték, ki az komédiában egy kurvának neve, avagy az Briseis névtűl formálta Blandrata, ki Achilles kurvája volt Homérusnál” (Italics mine Á.M.): "It may have been taken from the name Chrysa, which is the name of a whore in a comedy, or Blandrata formed it from the name Briseis, who was Achilles' whore in Homer", Szamosközy István történeti maradványai, p. 9.

21 On Biandrata's actual religious convictions, see: M. Balázs, "Giorgio Biandrata (1516-1588) - A Physician between Politics and Theology in Early Modern East Central Europe", in: Isabella Jagiellon, Queen of Hungary, pp. 277-303.

22 Balázs, "Giorgio Biandrata”, p. 282. 
Jan Zamoyski, although not all aspects of the latter relationship have been uncovered. ${ }^{23}$ In addition, Griseldis' story had found much more immense popularity in Poland than in Hungary. As we know from Grzegorz Franczak's monograph, a translation of the story had already been published in Poland before $1551,{ }^{24}$ and later another translation was prepared as a gift for the literate lady Helszka of Mortegi's marriage to Adam Żalinski in $1571 .{ }^{25}$ In the wife's family, a daughter was, in fact, named Gryzella two generations later. ${ }^{26}$ According to Franczak, as a result of the narrative poem (piękna historia), the Griseldis name became fashionable in Poland, which may have been the reason why the mother of Michał Korybut Wiśniowiecki, who was later elected Polish king, was also called Gryzella. The full name of Michał Korybut's mother was princess Gryzelda Konstancja Zamoyska (1623-1672). Gryzelda Konstancja’s father was Tomasz Zamoyski, i.e. hetman Jan Zamoyski's only child who had survived into adulthood, born to Zamoyski's fourth marriage. Thus, it seems that the name Griseldis (Polish Gryzelda) also recurred in the Zamoyski family. The Griseldis name could have been familiar to Zamoyski from his own native culture already from his childhood, since the first Polish translation of the story can be dated to before 1551, and he also could have become familiar with the story during his studies in Padua. Attending university in Padua may have given him cultural capital ${ }^{27}$ similar to that of Hungarian Pál Istvánffy before him, and later István Szamosközy and many other men who were educated in Padua. The Griseldis name as a symbol of obedience, together with the conversion, would have been a perfect expression of the new wife submitting herself to her husband's will. Basing on the facts above, I believe that the choice of the name Griseldis could have come from Jan Zamoyski

23 One piece published from their correspondence: Archiwum Jana Zamoyskiego, kanclerza i hetmana wielkiego koronnego, tomus III (1582-1584), ed. J. Siemieński (Warszawa, 1913), pp. 251-252. Reference to a letter, which was still unpublished in 1952: S. Łempicki, "Protektor medycyny i medyków", in: id., Renesans $i$ humanizm w Polsce. Materiaty do studiów (Warszawa, 1952), pp. 288-289.

${ }^{24}$ G. Franczak, Vix imitabilis: La Griselda polacca fra letteratura e cultura popolare (Kraków, 2006), p. 117.

25 Ibid., p. 143.

26 Ibid., p. 166.

27 On Zamoyski's cultural background see: A. Nowicka-Jeżowa, “Jan Zamoyski vir bonus et vere humanus", in: Humanizm między Wschodem a Zachodem, ed. M. Baraniak, A. Świder-Pióro (Warszawa, 2019), pp. 111-138. 
on his own accord, as it recurred later in his family, or it could have been suggested to him by the Saluzzo-born Giorgio Biandrata.

But why was it necessary for Kristóf Báthory's daughter to change her name? According to previous hypotheses, ${ }^{28}$ it was necessary because Jan Zamoyski's previous wife was also called Krystyna, and it would have been a problem to know if people were referring to deceased Krystyna Radziwiłł or living Krisztina Báthory when talking about Zamoyski's wife Krisztina. I consider this a weak argument since while she was living in Poland, King Stephen Báthory's niece always included 'Báthory', her family name at birth, in her signature, regardless of whether she was signing in Hungarian, Polish, or Latin. She gave her name in Hungarian in the following way: "nagy[ságos] Zamoiski Janosne Somlyaii Bathori Griseldis" 29 , in Polish "Griselda Bathorowna Zamoiska", ${ }^{30}$ and in the form of "Griseldis Bathori de Somljo" in Latin. ${ }^{31}$

I believe that the name change was not only necessary for the above-mentioned practical reason, we rather have to consider it a symbolic act that would have accompanied the bride's conversion to Catholicism. Both the girl's mother and grandmother did much for spreading Reformation in Hungary, and Kristóf Báthory's daughter followed them in her faith. ${ }^{32}$ Her mother, Erzsébet Bocskai, also supported the preparation of the first complete Hungarian translation of the Holy Scriptures (known as the Károli Bible or Vizsolyi Bible, printed by 1590) with a substantial amount. However, according to the expectations of Polish King Stephen and her future husband, the bride should have converted to the Catholic faith. The letters of Alberto Bolognetti, a nuncio living in Cracow, dealt a lot with the

28 I. Horn, Báthory András (András Báthory) (Budapest, 2002), p. 54.

29 VE-h, MS 433, photo copy of a letter, fragmented, unnumbered: "Datum Zamosc 22 majii Anno Domini 1589 kegy[elmednek] örömest szolgal az nagy[ságos] Zamoiski Janosne Somlyaii Bathori Grisledis m[anu] p[ropria]”.

30 VE-h, MS 433, copied on carbon from an original document, unnumbered.

31 Archiwum Jana Zamoyskiego, no. 920, p. 255.

32 According to the reports, the parents imparted their denomination according to the children's gender: the father raised the son as a Catholic, while the mother and the grandmother raised the daughter as Lutheran, Alberti Bolognetti nuntii apostolici in Polonia epistola et acta, 1581-1585, Pars 2: 1583, ed. E. Kuntze (Kraków, 1938; Monumenta Poloniae Vaticana, VI = hereinafter cited as MPV VI), no. 156, pp. 283-284: "sino in vita della madre havea procurato di levargliela, et n'havea scritto al prencipe suo fratello il quale anco si conformava (disse) a questo desiderio, ma per haver tolto il principino dalla educatione d'essa madre, giudicò di non dover levarle questa così presto per non essacerbarla tanto". 
issue from April 1583, ${ }^{33}$ when the marriage between Zamoyski and King Stephen's niece (who was regularly mentioned without a name) was already a publicly decided fact. From Rome's point of view, the main issue was that if the bride remained a Protestant, the nuncio could not give his blessing for the mixed marriage; what is more, he could not even officially appear at the wedding ceremony. ${ }^{34}$ According to Bolognetti's report, this prospect immensely angered King Stephen, who listed four or five royal couples for the nuncio, in whose cases the Catholic Church had also given its blessing for the mixed marriage. These included Polish Princess Catherine Jagiellon and Finnish Duke John in the first place. ${ }^{35}$ King Stephen's claims did not receive a response from Rome until five weeks after the wedding. According to Rome, the marriages he mentioned either did not take place, or one of the parties converted, or the priest performing the service only blessed the marriage due to fear under pressure. ${ }^{36}$

For centuries, religious conversion had been accompanied by the name change since, through the name, the parents also hoped to choose a fate for their children, and a new name also meant the beginning of a new life. The most famous example in Hungarian history is King Saint Stephen I, who traded his pagan Hungarian identity and the name Vajk for the name István when he was baptised. Aristocrats who were brought up in Byzantium, or those who were married there, also regularly received new names. For example, Hungarian King Béla III Árpád (1172-1196), when he was growing up in Constantinople as the heir of Emperor Manuel Komnenos, adopted the name Alexios. On the other hand, his second wife, Agnes Châtillon, used the name Anna in Byzantine baptism. ${ }^{37}$

33 MPV VI (1583), no. 126, p. 229, 10 April; no. 137, p. 246, 22 April; no. 156, p. 283, 6 May; no. 184, p. 332, 30 May; no. 193, p. 343, 10 June.

34 MPV VI, no. 193, p. 343, 10 June 1583: "Di che Sua Maestà ha mostrato sdegno più che mediocre, et s'è mandato a doler meco, con'anco poi ha fatto in voce, allegando l'essersi data la benedittione da un vescovo alla Regina di Svetia quando si maritò con quel principe heretico...”.

35 On Catherine Jagiellon's marriage and difficulties: S. Niiranen, "Counting Family Bonds after Death: Catherine and Isabella", in: Isabella Jagiellon, Queen of Hungary, pp. 132-137.

36 MPV VI, no. 246, p. 426.

37 Á. Máté, Fabula és história határán. A magyarokkal kapcsolatos sztereotípiák és vándoranekdoták itáliai elbeszélö forrásokban [At the border of fabula and history. Stereotypes and wandering anecdotes related to Hungarians in Italian narrative sources] (Szeged, 2018), p. 199. 
During the sixteenth century, after the council of Trent, the Catholic Church paid even more attention to religious formalities than before. ${ }^{38}$ The pope would have likely found it especially reassuring if the Polish Catholic king's niece and the chancellor's wife, beside changing her religion, had expressed her commitment to Catholicism by also changing her name. ${ }^{39}$ Faith played a crucial role in Jan Zamoyski's life, and it was during his studies in Padua (1561-1564) that he converted to the Catholic faith from the Calvinist religion he had inherited from his father. Jan Zamoyski might have initiated his fiancée's name change because his second wife, Krystyna Radziwilt, had also converted from Calvinism to Catholicism, but she died three years after the wedding. Zamoyski might have wanted to ward off the bad omen and prevent the repetition of his previous wife's fate through his third wife also converting to Catholicism as well as being called Krisztina. This train of thought might sound strange for a modern person with a secular way of thinking. However, according to a letter from Papal Legate Antonio Possevino, Zamoyski indeed seriously believed that the deaths of his non-Catholic relatives, including that of his second wife, was God's punishment for him, and he was afraid that if his new wife did not convert, God would take her from him as well. ${ }^{40}$

38 The conversion could have been a symbolic present for the Pope, which András Báthory would have placed at his feet during his trip to Rome, MPV VI, no. 247, p. 432, 23 July 1583: "Questo della riduttione della sposa è uno dei duoi presenti che spesso ho detto con Sua Maestà dovria portar il Signor Andrea a Nostra Santità nell'andata sua a Roma”.

39 On the role of the Báthory family in the counter-reformation movement in Transylvania see: T. Kruppa, "A katolikus megújulás ügye Erdélyben a Báthory-korszakban (1580-1605)" [Catholic reform in Transylvania during the Báthory era], in: Catholice reformare: A katolikus egyház a fejedelemség korában [Catholice reformare: the Catholic Church during the Principality], ed. D. Diósi, J. Marton (Kolozsvár-Budapest, 2018), pp. 157-237. For the preference of King Báthory for Catholic office holders in the Crown's lands see: K. Bem, "Czynnik wyznaniowy w polityce nominacyjnej Stefana Batorego na starostwa grodowe w koronie - początek kontrreformacji?”, Kwartalnik Historyczny 122, no. 3 (2015), pp. 457-473.

40 MPV VI, no. 242, pp. 414-415, 16 July 1583: "et che già in due diete di Varsavia et hora dopo queste nozze gli erano morte una moglie havuta, et il marito di una sua nipote heretica, et un'altra ad esso pure heretica maritata col tesoriere di questo Regno, in che doveva considerare, che Dio gli dava santi avisi, per ormai porre in più viva pratica quella fede et doni ch'egli haveva, mi rispuose alquante buone cose. Et dapoi mi disse ch'io volessi, come da me 
Considering all the information presented above, it seems most likely that the change of the young Báthory girl's name was initiated at the court of Cracow, and it was motivated by personal choices of her future husband, Jan Zamoyski, and by the propagandistic goals of her uncle, Polish King Stephen Báthory, whom both wanted the bride to convert to the Catholic faith.

Act Two. Characterising Griseldis Based on the Prints Saluting the Wedding

After crossing the Polish border, Kristóf Báthory's daughter thus changed from Krisztina to Griseldis, as her name in the prints connected to the wedding celebrations reads. Among these prints, the poem by Schreckius from Danzig (Gdańsk), Istula sive gratulatio, contains information on the bride that the public might have heard about even before she arrived in Poland. In contrast, Priscovius' Gratulatio, which he wrote in the name of the Polish nobility, and which he only published in the year after the wedding, indicates a closer acquaintance between the author and the bride, from the time when Griseldis was already residing in Cracow. The two different perspectives shed more light on how epithalamia, having been regularly prepared ante festa ${ }^{41}$ depicted foreign brides in an ideal way. Then, the foreign partner became a woman, flesh and blood only after her arrival, and she could finally prove herself to be the ideal person depicted before. However, scholarship rarely has at its disposal different works celebrating the same wedding with different perspectives before and a bit after the event. Comparing the poem by Schreckius to the Gratulatio by Priscovius, one can guess that for her physical beauty and culture,

stesso, farò opra co'l Re che dalla moglie si lievasse il suo maggiordomo Ungaro ch'è heretico, percioché sperava di ridurla così facilemte ad ogni sorte di pietà, aggiungendo che non ardiva a questa sorte di cose trattare così liberamente co'l Re, acciocché non suspicasse Sua Maestà ch'egli havesse già disgusto di sua nipote ch'è a lui moglie".

41 In an extreme case an epithalamium was prepared, but the marriage did not take place. Johannes Franciscus Marlianus, indeed, wrote a long oration with the title epithalamium for the proxy wedding of Johannes Corvinus, son to Hungarian King Matthias Corvinus, with the Milanese Princess Bianca Maria Sforza, but the bride never came to Hungary, and finally became wife to Emperor Maximilian I Habsburg in 1493; see Á. Máté, “A volterrai epithalamium-corvina: egy elvetélt házasság mementója” [The epithalamium corvina of Volterra: memento of an abolished marriage], Irodalomtörténeti Közlemények 124, no. 4 (2020), pp. 496-511. 
Griseldis Báthory was not a disappointment to the scrutinising eyes in her new country.

The Istula sive gratulatio text by Schreckius says that the bride is the daughter of Polish King Stephen Báthory's brother Kristóf, Prince of Transylvania, and that the family comes from Máramaros county, from the area where the Tisza River originates. ${ }^{42}$ The bride was her mother's only daughter, and she had famously raised her to be a beautiful and chaste woman as well as abounding in other virtues, and she was married off by his uncle, following her father's death (in fact, the death of both her parents). Her selected husband was Zamoyski, who had lost his first love, Krystyna Radziwiłł $^{43}$ (for some reason, Zamoyski's first wife, Anna Ossolińska, is not mentioned either here or in the Gratulatio), and now he was entering his second (in fact, his third) marriage. Using the rhetorical device of retardatio, the poet only says the bride's name after these: "Dum venit illustri illustris socianda marito / GRISILDIS castum thalami ascensura cubile." It is interesting that towards the end

42 Schreckius, Istula sive gratulatio, B2r ${ }^{\mathrm{r}}$, lines 5-26: "Huic decori herois se gloria coniugis aequat, / Quae venit illustris thalamo adducenda mariti, / Illustris sponsa, et proavis illustribus orta, / Filia enim Regis Stephani est ex fratre creata / Christophoro, dives quo Transsylvania nuper / Ultra Danubii tractus, collesque nivosos / Carpathi, ab antiquis Dacorum habitata colonis / Principe gaudebat, qui servantissimus aequi / Regna data ac populos tranquilla in pace regebat / Quique genus, Batoraeorum de sanguine duxit, / Antiquum genus, et multis virtutibus olim / Cognitum in imperio Regum, quis Pannonis ora / Et Dravus, Maromarusioque e monte Tibiscus / Paruit egrediens: genus hoc Regemque Polonum / Progenuit nobis Stephanum, sponsaeque parentem / Christophorum: atqui illam mater studiosius unam / Eduxit forma insignem, insignemque pudore, / Egregiamque aliis virtutibus heroinam, / Quam pater excedens vivis post fata reliquit, / Rex sed eam, meritis ultro sua praemia reddens, / Ex quo primus amor Samoiscum morte fefellit / Coniugis, illustri Radivili e stemmate natae".

43 Ibid., B2v, lines 1-17: "Christinae, ante procos alios Samoiscio habendam / Foedere connubii iunxit, propriamque dicavit, / Iamque dies ni fallor adest, quo regia virgo / Illustri primos cum coniuge somnos, / Namque ita, Carpathiae surgens dum rupis ab antro / Moenia praetereo veteris de nomine Grachi, / Audire haec memini, nec me radiantia Solis / Lumina, quae ingentis collustrant moenia mundi, / Atque nitore novo conspergunt undique montes, / Immemorem fallunt: video revolubilis axem / Aetheris insolito laetum signa edere plausu, / Iam stratum silet aequor, et arcent flamina venti, / Subiectis ridet nunc aura salubrior oris / Et natura novos nuptis gratatur honores, / Dum venit illustri illustris socianda marito / GRISILDIS castum thalami ascensura cubile, / Perpetuosque habitura novo cum coniuge honores". 
of the poem, ${ }^{44}$ the spelling of the female name changes: "Herois SAMOISCI, et amabilis heroinae / CHRISILDIS, tibi commendo: quos aureo amantes / Expectata diu, lux haec coniungit amore". This version can be explained based on the context, i.e. from the expression "aureo amantes" at the end of the line. According to this, the poet originates the female name from the Greek word $\chi \rho v \sigma o$, meaning 'gold'. This etymology is the complete opposite of István Szamosközy's explanation mentioned above, which linked the origin of the Griseldis name to the women of dubious morals known from antiquity.

In contrast, Gratulatio, written in the name of the Polish nobility, descriptively talks about Griseldis, ${ }^{45}$ and it also addresses her personally several times. ${ }^{46}$ Addressing Zamoyski, the text praises the bride's beauty (dignitas formae), superseded by her eloquence (eruditio), which she had also displayed in Latin. Added to this are her morals, chaste modesty (virginalis verecundia), and her pleasant

44 Ibid., B3 ${ }^{\mathrm{r}}$, lines 5-15: "Hinc etiam optatos thalami praelustris honores / Herois SAMOISCI, et amabilis heroinae / CHRISILDIS, tibi commendo: quos aureo amantes / Expectata diu, lux haec coniungit amore. / Sit felix coepti auspicium, sint omnia fausta / Ambobus: triplex genialem Gratia lectum / Ambiat, aeternumque ambobus foedera nectat. / Et rata perpetuum Concordia foedera firmet, / Unde Samoiscae stirpis Batoraea propago / Surgat, et illustres referat virtute parentes, / Et patrium factis illustribus impleat orbem".

45 Piscorevius, Gratulatio, E1 ${ }^{\mathrm{r}}-\mathrm{E} 2^{\mathrm{r}}$ : "Tacebo etiam de dignitate formae: caducum id et breve bonum est, sed tamen bonum: et hac sponsa tua, regius sanguis, eximia est. Primum est ea aetate, cui tu tanta prudentia vir, pro tuo arbitratu moderabere, non cuius imperia subeas. Eruditionem eius perspexisti. Oratio illius latina, neque ea rudis. Hanc subsequuntur suavissimi mores: virginalis verecundia, $\left[\mathrm{E} 2^{\mathrm{r}}\right]$ flos aetatis commendat iucundissimus aspectus, concordat gravis iam, et plane matronalis prudentia. Quis a puellaribus annis expectasset? annos dico cum sexum adeo transgressa videatur. Brevius omnino curriculum est virtutis, quam aetatis. Tarda ingenia annorum intervalla requirunt. Haec te Reipublicae curis defessum venientemque senatu excipiet, haec solicitum recreabit, laetissimis tuis rebus optatissima comes, in humanis perferendis, qui tot in dies accidunt, expetenda adiutrix, fortunarum omnium rerumque domesticarum, vitae tuae incorruptissima custos. Tu reintegratis viribus, ad optimum Regem, tu in senatum, in curiam ad iudicia semper recens venies, rerum tuarum illa domi relicta securus Reipublicae solicitus. Te autem, fortunatissima Griselda, quibus verbis affabor?".

46 Ibid., E4 ${ }^{\text {r: }}$ "Haec apud te diligentius prudentissima Griselda, vide an a tuo patruo acerrimi iudicii Rege tantus vir iniuria ametur, si iuste, si pie, si grate, illi te potissime sponsam, illum tibi potissime maritum delegit, potes iudicare, ingeniosissima es, praestas iudicio”. 
appearance fitting her blooming youth, which is already accompanied by wisdom fitting a serious, mature woman (prudentia). This characteristic transcends both her young age and her female gender. Her features make her worthy of being her husband's helper, partner, and guardian of his household. The orator then turns to Griseldis directly and praises Zamoyski's virtues at length. What may be surprising in these lines is that the orator also believes Griseldis worthy and capable of judging all this since she "ingeniosissima es". Both texts contain the well-wishes typical of epithalamia as to being blessed with many children, and the bride's characterisation and the designation of her tasks thus ends.

Through the imagination of Schreckius in the Istula sive gratulatio, one sees the arrival of an ideal bride. Thanks to Priscovius' work, one can have an impression of the sympathy for the actual Griseldis and the Polish political elite's high expectations of her. To complete the picture, one also has to look at the inner circles of Griseldis' own life.

Act Three. Reality Bites

Several family members, Protestant aristocrats, and servant staff arrived in Cracow in the Transylvanian bride's 500-person entourage, protected by 600 soldiers. ${ }^{47}$ Her prominent entourage included representatives of the inner circles of the court in Gyulafehérvár, such as János Ifffú, Pál Perneszy, Kristóf Bánffy, and György Bánffy, Gábor Csáky, Miklós Gávay, György Bebek, László Boronkay, and György Palatics. The female entourage was led by the bride's grandmother, Krisztina Györgyné Bocskay Sulyok, whom the bride had been initially named after, and from whom she had also taken her firm Protestant conviction. They were joined by György Bebek's wife Zsófia Pathócsy, as well as György Bánffy's wife Anna Perneszy. The bride's immediate retinue was led by her secretary, János Cséffey, as well as her two magistri curiae, György Lencsés and Miklós Orbai. Besides Heidenstein's letter, ${ }^{48}$ the names of the most important members of the aristocratic entourage were also preserved by a contemporary chronicle, recording the Hungarian names with quite a lot of mishearing and misspelling. ${ }^{49}$

47 VE-h, MS 433, p. 23.

48 De Nuptiis Illustrium Ioan. De Zamoscio, B2 ${ }^{\mathrm{r}}$.

49 E. Dubas-Urwanowicz, "Wesele Jana Zamoyskiego z Gryzeldą Batorówną", Biatostockie Teki Historyczne 9 (2011), p. 242. 
We know from Nuncio Bolognetti's increasingly impatient letters that Griseldis refused to convert. She was supported in her faithfulness to the Protestant cause by her Hungarian relatives and courtiers, ${ }^{50}$ and she married Jan Zamoyski as a non-Catholic. ${ }^{51}$ Due to the denominational difference between the couple, not the nuncio blessed the marriage but Marcin Białobrzeski, bishop of Kamieniec, ${ }^{52}$ whom the bride already knew. King Stephen Báthory had indeed sent the Polish bishop to Transylvania at the beginning of 1583 with the mandate to celebrate Prince Kristóf Báthory's funeral and bring the bride to Poland on the return journey. Nuncio Bolognetti, due to the mixed marriage, only attended the series of wedding celebrations at Jan Zamoyski's personal invitation, not as an official representative of the Catholic Church. ${ }^{53}$ During dinner, the nuncio could also personally ascertain the strong personality of Krisztina Sulyok, who had brought Griseldis up after her mother's death. Although she, contrary to her daughter and granddaughter, did not speak Latin, so she only conversed with the help of an interpreter, Bolognetti concluded that the bride's grandmother was "una signora di gran spirito". This conclusion is further strengthened by the report in which Bolognetti passes along what he had heard about Krisztina Sulyok from King Stephen. ${ }^{54}$

50 MPV VI, no. 156, pp. 283-284, 6 May 1583: "Pare però che il Signor cancelliere dubiti se questa riduttione della sposa possa seguire innanzi le nozze, et tanto più è da dubitarne, venenedo questa giovine sotto la cura di sua avia heretica, et accompagnata da molte altre signore, tutte heretiche"; ibid., no. 184, p. 332, 30 May 1583: "il Re mostrava di temere grande impedimento dall'avia et dall'altre matrone che la conducono, diceva che, dopo la partita loro, si potria fare difficoltà quel che hora sarà difficilissimo".

51 MPV VI, no. 198, p. 354, 13 June 1583: "La sposa non si è convertita altrimenti...".

52 Zamoyski's own comment on the fact: "nikogo nawracać nie chcę, ani jej przywodzić nie będę, tego też jej bronić nie będę, aby nie miała przede mną wiary swej wyznawać, a on też jej swojej. I na tem też stanęło", Dubas-Urwanowicz, "Wesele Jana Zamoyskiego", p. 241, n. 17.

53 MPV VI, no. 212, p. 377. "Mostro esso Signor cancelliere che gli sarebbe stato caro ch'io vi fossi intervenuto [...] essendo intervenuto non solamente al primo banchetto ma ancora agl'altri due [...] et il secondo giorno volse anco che cenassimo Monsignor di Plozca et io domesticamente con quelle Signore Ungare, parenti di Sua Maestà, tra le quali mi parve di conoscere che quell'avia materna della sposa fosse signora di gran spirito, et non intendendo ella latino, come sua figlia et la sposa, sua nipote, il Signor Baldassar faceva l'interprete".

54 MPV VI, no. 247, p. 431: "Sua Maestà fece una longa digressione in dirmi delle qualità di quella matrona et del ragionamento ch'havea havuto seco per 
When the king and Krisztina were debating matters of religion, Krisztina Sulyok told the king that if he could convince her that she was the one in religious error, she would convert to Catholicism. However, since her husband and other relatives had left this life with such great faith, it was inconceivable that they were not resting in God. It is especially telling that King Stephen, at least in Bolognetti's interpretation, does not even consider Krisztina Sulyok's reasoning worthy of debate; instead, he dismisses it with an argument deduced from her gender (argumenta a persona: sexus), in other words, he labels it "female logic" to invalidate it: "con altre simil ragioni donnesche".

It is likely that her female ancestors not only took care of Krisztina-Griseldis financially ${ }^{55}$ and passed their religious conviction on to her, but they also taught her the skill to argue in favour of their faith. According to Nuncio Bolognetti's report, when the bride's entourage set out on their journey back to Transylvania after the wedding, a tearful Krisztina Sulyok made her granddaughter swear not to leave the Lutheran faith she was raised in. ${ }^{56}$ It must have been a dramatic moment when the grandmother, who had accepted that her granddaughter would bear a new name instead of her own in her new homeland, warned the girl to always stay unyielding in matters of the soul. Griseldis indeed did so: during the summer of 1583, Bolognetti and Possevino wrote in several letters that the young wife, despite the king's and her husband's prohibition, regularly visited the Bróg in Cracow to listen to Lutheran sermons. ${ }^{57}$ Despite her adopted name and young age, she was disobedient and did not subject herself to her husband's will at all. Griseldis did not show any willingness

ridurla a qualche buon segno, si come disse che l'havea ridotta a prometterle che quando se le mostrasse il suo errore, si farebbe cattolica, benché prima allegasse le morti del marito et altri suoi parenti seguite con tanta divotione, che non si potea indurre a credere che non obdormissent in Domino, con altre simili ragioni donnesche".

55 MPV VI, no. 156, pp. 286-287, 26 May 1583: "Il qual riferisce ancora che la sposa s'apparecchiava di venire con splendore grandissimo, et che portava seco da 200 mille scudi di gioie et altre cose pretiose lasciategli dalla madre".

56 MPV VI, no. 247, p. 431: "l'avia sua la quale al suo partire con le lagrime agl'occhi l'havea pregata e scongiurata per l'amor di Dio, per l'affettione che portava a lei et all'anima della madre sua, che non volesse abbandonare quella religione".

57 MPV VI, no. 225, p. 392; no. 227, p. 398; no. 247, p. 431; no. 249, p. 439; no. 326, pp. 582-583. 
to convert to the Catholic faith nolens volens, as King Stephen had promised to the nuncio and Chancellor Zamoyski. ${ }^{58}$

As the summer progressed, Chancellor Zamoyski faced an increasing confessional struggle due to his wife's religious views. As I mentioned above, according to one of Antonio Possevino's letters, the hetman was sincerely afraid that due to her Lutheran faith, God would punish this wife of his with death as well, as it had happened to several of his "heretic" family members before. ${ }^{59}$ King Stephen, Queen Anna, and the representatives of Rome finally decided in Cracow to strip Griseldis of her "heretic" environment; that is, they gradually dismissed the staff she had brought from home. From Possevino's letter of 9 July 1583, we learn that Griseldis' Latin tutor (maestro di latinità) had already been sent back to Transylvania, and they were about to remove her preacher (il ministro) as well. ${ }^{60}$ In addition, on $23 \mathrm{July}$, Bolognetti wrote that her preacher, her magister curiae (maestro di casa), János Perneszy, and her ladies-in-waiting, who were all heretics, were still beside Griseldis. ${ }^{61}$ Citing King Stephen, Bolognetti claimed that they did not want to remove the female staff from Griseldis' side, which Queen Anna quite resented. ${ }^{62}$ The king made a promise to change the magister curiae, although Perneszy had been in the service of the family for a long time and did not flaunt his denominational

58 MPV VI, no. 156, p. 283, 6 May 1583: "il Serenissimo Re [...] mi disse con parole molto risolute: "Converrà ch'ella sia cattolica, o voglia o non voglia".

59 MPV VI, no. 242, pp. 414-415, 16 July 1583.

60 MPV VI, no. 231, p. 403: "la moglie et gli errori di lei et la conseguenza del male che potrebbe seguire, se non rimuove da lei un certo heretico predicatore Unghero, come però ha già fatto del suo maestro di latinità, rimandandolo in Transilvania”.

61 MPV VI, no. 247, p. 431: "restano il ministro, il mastro di casa e le damigelle heretiche. Di mutar le damigelle non si parla, et questo dispiace grandemente alla Serenissima Regina, del mastro di casa la Maestà del Re m'ha promesso di mutarlo subito che trova un altro a proposito, sebbene dice che non parla mai di quella sua religione come discretissimo et modestissimo, et è servitore antico della casa. Quanto al ministro dice Sua Maestà che può facilmente mandar via costui da un'hora ad un altra, ma che dubita d'indurar tanto più l'animo della giovane con mostrar di voler tenere la via della forza, et che però vorrebbe che per via del suo colloquio o alto valent'huomo si potesse (se non voltare) almen convincer $[\ldots]$ soggiunse ridendo Sua Maestà: "Potrò provar io ancora se potessi io convincerlo con una mazza di fiorini, et in tal caso l'acquisto della giovene seguirebbe senza difficoltà «".

62 By the fall Queen Anna had lost faith in Griseldis ever converting, MPV VI, no. 301 , p. 535. 
affiliation, so he would not have preferred to remove them from his niece's side. King Stephen's reluctance is understandable since these persons in positions of trust served to ensure the young wife's basic comfort in her new environment; they knew her habits and spoke her language, which would not have been true of the Polish-speaking and Catholic ladies-in-waiting haphazardly appointed by Queen Anna. King Stephen was willing to send away Griseldis' preacher, but he did not want to create the appearance of spiritual coercion in her. Clearly, the king, the queen, and the husband wanted Griseldis to become Catholic of her own conviction, by her internal spiritual motivation, and they did not think it would be possible through coercion. ${ }^{63}$ King Stephen also personally taught Griseldis about matters of faith, and he had her be given books aimed at proselytising. ${ }^{64}$

According to the last available data, again supplied by a letter from Nuncio Bolognetti, the preacher was still a member of Griseldis' court on 1 October 1583, for which her husband, Chancellor Zamoyski, was harshly criticised both by Legate Bolognetti and by Queen Anna. According to Bolognetti, who quotes Hetman Zamoyski verbatim, Zamoyski seemed to have grown tired of the debate by this time. On the one hand, he lamented that his wife paid more attention to her Hungarian preacher in matters of spirituality than himself. On the other hand, he also likely understood that a wife's love for her husband and the faith in divine truth according to her own denomination could not compete with each other in Griseldis' soul. It was as if the religious conviction was even more important than the commandments of loving one's husband and obedience. Zamoyski concluded the debate with the nuncio and the queen by saying that in such a short period (they had barely been married for four months), he had not been able to convert his two previous wives either and that resisting a wife's will did more harm than good if they needed to be convinced about something. ${ }^{65}$

63 MPV VI, no. 137, p. 246, 22 April: "Tuttavia [Zamoyski] soggionge che, quando ella si mostrasse dura in questo principio, non potendo esso forzarla in cosa tale, andrebbe disponendo materia a poco a poco".

${ }^{64}$ MPV VI, no. 249, p. 439, 24 July. See the texts he sent to the Protestant members of his court and family, all written in a Catholic spirit: Á. Mikó, "Báthory István király és a reneszánsz művészet Erdélyben (1576-1586)” [King Stephen Báthory and the renaissance art in Transylvania (1576-1586)], Müvészettörténeti Értesitö 37, no. 3-4 (1988), pp. 115-119, here: 127-132.

65 MPV VI, no. 326, pp. 582-583, 1 October 1583: “m’haveva detto più volte la Serenissima Regina, et che non è punto meno scandaloso, cioè ch'esso Signor 
It seems that Endre Veress did not find any proof that the operations trying to convert Griseldis had continued, either. Namely, the documentation in the Veress Estate does not discuss the issue of the wife's religious affiliation during the remaining seven years of Griseldis' life. Neither is the name of the Hungarian preacher serving with her revealed from the documents, nor whether he was eventually successfully removed from Griseldis' side. Nevertheless, it is clear that Griseldis took care of the members of staff dismissed during the summer of 1583 with her uncle's help. According to the data surviving in the correspondence between King Stephen and Transylvania, a man called Zsigmond Romány, ${ }^{66}$ scribe Mátyás Válaszúti, ${ }^{67}$ a woman called Péterné Bernárd, ${ }^{68}$ and scribe Ferenc received benefices at Griseldis' request and from the Transylvanian triple council at King Stephen's intervention. The woman is mentioned as Griseldis' housekeeper; thus she could have been in charge of running the household. Scribe Ferenc is mentioned as "master of her highness wife of the chancellor", ${ }^{69}$ i.e. he was likely Griseldis' dismissed Latin tutor.

cancelliere lasciò predicar il ministro Ongaro in casa sua che e contigua al palazzo et dirimpetto alla chiesa, et non sapendo il Signor cancelliere rispondere altro a quello: "Non si metta (disse) più fastidio Vostra Santità, ch'io ho cacciato di casa questo tristo et mi son anco dovuto in mia moglie che dica di voler meglio a me ch'a tutti gli huomini del mondo, poi mostri maggior affetione al ministro, credendo più alle parole sue che alle mie.« [...] Ma sen'accorse (per quanto credo) perché esso medesimo [Zamoyski] poi mi riferse quel che gl'havea detto la Serenissima Regina, et disse d'haver risposto: „Vostra Maestà dovria pur saper la natura delle donne la qual è tanto ritrosa che con contraddirgli et con essacerbarle si fa peggio "”.

66 Báthory István király levélváltása az erdélyi kormánnyal: 1581-1585 [The Correspondence of King István Báthory with the Transylvanian Government: 1581-1585], ed. E. Veress (Budapest, 1948), no. 33, p. 65, 26 June 1583. Based on the date, he returned to Transylvania with Krisztina Sulyok and her entourage.

67 Báthory István király levélváltása, no. 34, p. 64, 26 June 1583. He was also a likely member of the entourage returning to Transylvania. There is data referring to his noble ancestry from 1580 at the town of Dés (today's Dej in Romania), A. Szász, "Dés városvezetése 1541-1600 között" [City administration in Dés between 1541-1600], Erdélyi Múzeum 80, no. 1 (2018), p. 56, n. 18. In addition, from 1590 on, he also appears several times as a landowner in the settlement of (Szász)Nyires (today’s Nireș in Romania), K. Tagányi, Szolnok-Dobokavármegye monographiája [Monograph of county Szolnok-Doboka] (Dés, 1901), vol. 5, p. 267.

68 Báthory István király levélváltása, no. 39, p. 77, 6 August 1583.

69 Ibid., no. 49, p. 104, 3 October 1583. 
Griseldis herself requested benefices in 1584 for a man called András Pap, who had been serving both her father and herself since her childhood, who also likely returned to Transylvania from Poland. ${ }^{70}$ Therefore, the available data suggests that Griseldis Báthory did not change her faith despite the displacement of her Transylvanian people from her Polish household.

\section{Epilogue}

Griseldis Báthory's marriage to chancellor Jan Zamoyski can be considered a genuine failure for the Counter-Reformation movement following the council of Trent. The young wife, who came from a prestigious house, had received an excellent education, including Latin curriculum, stood out among women according to the cultural standards of her time, and from this perspective, she could have been an ideal wife for an important political player such as the second most important person after the Polish king. However, Griseldis had been brought up as a Lutheran in the household where the children's denomination was based on the child's gender in the case of parents of different religions. The religious difference between bride and groom had posed a problem since the marriage planning between Zamoyski and Griseldis, but the Catholic party thought it could be resolved. The wedding, constituting the culmination of celebrating the victorious campaign led by King Stephen and Chancellor Zamoyski, was conducted among the greatest formalities. According to my argumentation above, changing the bride's Christian name at birth in Poland would have been part of this long series of celebrations, a symbolic act. This symbolic deed was supposed to express that king Stephen and his chancellor, having defeated tsar Ivan the Terrible, who had also promised the pope to convert to Catholicism, could now start mending the other significant problem of the papacy, i.e. converting those "of heretic beliefs". The best place to start this monumental plan would have been his own family, converting his niece, Krisztina Báthory, to Catholicism. However, this process was cut short: Kristóf Báthory's daughter only received a new name in her new homeland, but she never reached the spiritual conviction which would have led to the acceptance of the Catholic doctrine. They renamed the shrew, but her taming remained incomplete.

70 Ibid., no. 72, p. 185, 27 August 1584. 


\section{Bibliography}

\section{Sources}

Archival Sources

Veress Endre-hagyaték (Endre Veress Estate), MS 433, Budapest, Magyar Tudományos Akadémia Könyvtár és Információs Központ, Kézirattár (Library and Information Centre of the Hungarian Academy of Sciences, Manuscripts Archive)

Printed Sources

Ad Illusstrissimum D. Ioannem Zamoiscium R. P. Cancellarium. Et Exercituum Imperatorem. De Nuptiis cum Illustriss. Domina D. Griselide Bathorrea, Translyvanieae nata principe, Serenissimi Poloniae Regis Stephani primi, fratris filia, contractis. Idibusque Iunii celebratis. Cracoviae. Matthei Piscorevii Gratulatio (Cracoviae, 1583)

Alberti Bolognetti nuntii apostolici in Polonia epistola et acta, 1581-1585, Pars 2: 1583, ed. E. Kuntze (Kraków, 1938)

Archiwum Jana Zamoyskiego, kanclerza i hetmana wielkiego koronnego, tomus III (1582-1584), ed. J. Siemieński (Warszawa, 1913)

Báthory István király levélváltása az erdélyi kormánnyal: 1581-1585 [The Correspondence of King István Báthory with the Transylvanian Government: 1581-1585], ed. E. Veress (Budapest, 1948)

Caligarii I.A. nuntii Apostolici in Polonia epistolae et acta 1578-1581, ed. L. Boratyński (Kraków, 1915), [Monumenta Poloniae Vaticana, IV]

Cochanovii I., Ad Stephanum Bathoreum Regem Poloniae inclytum Moscho debellato, et Livonie recuperata. Epinicion (Cracoviae, 1583)

Cochanovii I., In Nuptias Illustrium Ioan de Zamoscio, R. P. Cancellarii, et exercitum Praefecti: Ac Griseldis Bathorrheae Christophori Transilvaniae principis et Sereniss. Stephani Poloniae regis fratruis, filiae. Epithalamion (Cracoviae, 12 June 1583)

De Nuptiis Illustrium Ioan. De Zamoscio R. P. Cancellarii execitt. Praefecti: Ac Griseldis Bathorreae, Christophori Transilvaniae principis, et Sereniss. Stephani Poloniae Regis fratris filiae: Ad Illustrissimum Principem Georgium Fridericum Marchionem Brandenburgen. in Prussia Ducem R. H. S. R. Epistola (Cracoviae, 1583)

Ghymesi Forgách Ferenc magyar históriajja 1540-1572 [The Hungarian history of Ferenc Ghymesi Forgách 1540-1572], ed. F. Majer, F. Toldy (Pest, 1866), [Monumenta Hungariae Historica: Scriptores, 16]

Kochanowski J., Carmina latina, Pars III. Commentarius, fecit Z. Głombiowska (Gdańsk, 2013), pp. 233-251

Schreckius V., Istula sive gratulatio Ad Illustrem magnificum et generosum Dominum Ioannem Samoiscium de Zamoiscze: Inclyti Regni Poloniae Capitaneum generalem et Cancellarium etc. (Gdańsk, 1583) 
Szamosközy István történeti maradványai: 1566-1603, IV. Vegyes feljegyzések [István Szamosközy’s historical remainders: 1566-1603, IV. Mixed notes] (Pest, 1876-1880)

\section{Secondary Works}

Ács P., "Boccaccio Baranyában. Egy kivételes értelmiségi pálya a 16. század első felében: Istvánffy Pál" [Boccaccio in Baranya County. An Exceptional Intellectual Career in the First Half of the Sixteenth Century: Pál Istvánffy], in: "A magyar történet folytatója". Tanulmányok Istvánffy Miklósról ["Who continued Hungarian History": Essays on Miklós Istvánffy], ed. P. Ács and G. Tóth (Budapest, 2018), pp. 37-58

Balázs M., "Giorgio Biandrata (1516-1588) - A Physician between Politics and Theology in Early Modern East Central Europe", in: Isabella Jagiellon, Queen of Hungary (1539-1559). Studies, ed. Á. Máté, T. Oborni (Budapest, 2020), pp. 277-303

Bem K., "Czynnik wyznaniowy w polityce nominacyjnej Stefana Batorego na starostwa grodowe w koronie - początek kontrreformacji?", Kwartalnik Historyczny 122, no. 3 (2015), pp. 457-473

D'Elia A.F., The Renaissance of Marriage in Fifteenth-Century Italy (Cambridge, MA - London, 2004)

Dubas-Urwanowicz E., "Wesele Jana Zamoyskiego z Gryzeldą Batorówną", Biatostockie Teki Historyczne 9 (2011), pp. 237-251

Franczak G., Vix imitabilis: La Griselda polacca fra letteratura e cultura popolare (Kraków, 2006)

Griselda, metamorfosi di un mito nella società europea. Atti del Convegno internazionale a 80 anni dalla nascita della Società per gli studi storici della provincia di Cuneo, Saluzzo, 23-24 aprile 2009, ed. R. Comba et al. (Cuneo, 2011)

Horn I., Báthory András (András Báthory) (Budapest, 2002)

Horn I., "Báthory István uralkodói portréja" [Stephen Báthory’s portrait as a sovereign], in: Politikai propaganda és reprezentáció a kora újkorban [Political propaganda and representation in early modernity], ed. N. G. Etényi, I. Horn (Budapest, 2008), pp. 363-400

Komlóssy Gy., "La storia di Griselda come regalo di nozze", in: Griselda, metamorfosi di un mito nella società europea. Atti del Convegno internazionale a 80 anni dalla nascita della Società per gli studi storici della provincia di Cuneo, Saluzzo, 23-24 aprile 2009, ed. R. Comba et al. (Cuneo, 2011), pp. 145-154

Kowalczyk J., "Mars i Parys. Uroczystości tryumfalne i weselne w Krakowie w 1583 r.", in: J. Kowalczyk, W kregu kultury dworu Jana Zamoyskiego (Lublin, 1980), pp. 103-159, 290-298

Kruppa T., "A katolikus megújulás ügye Erdélyben a Báthory-korszakban (1580-1605)" [Catholic reform in Transylvania during the Báthory era], 
in: Catholice reformare: A katolikus egyház a fejedelemség korában [Catholice reformare: the Catholic Church during the Principality], ed. D. Diósi, J. Marton (Kolozsvár-Budapest, 2018), pp. 157-237

Kruppa T., Tradició és propaganda keresztútján. Fejezetek Báthory Zsigmond udvarának kultúrájából [At the Crossroads of Tradition and Propaganda: Chapters on the Culture of the Court of Zsigmond Báthory] (Budapest, 2015)

Łempicki S., "Protektor medycyny i medyków", in: id., Renesans i humanizm w Polsce. Materiaty do studiów (Warszawa, 1952), pp. 280-292

Máté Á., Fabula és história határán. A magyarokkal kapcsolatos sztereotípiák és vándoranekdoták itáliai elbeszélo" forrásokban [At the border of fabula and history. Stereotypes and wandering anecdotes related to Hungarians in Italian narrative sources] (Szeged, 2018)

Máté Á., "Il ruolo di 'capro espiatorio' delle regine, ovvero la favola Griselda come speculum reginae nella storia ungherese", Rivista di Studi Ungheresi 15 (2016), pp. 7-23

Máté Á., "A Literary Image of Renaissance Queenship: the Marriage of Isabella Jagiellon", in: Isabella Jagiellon, Queen of Hungary (1539-1559). Studies, ed. Á. Máté, T. Oborni (Budapest, 2020), pp. 39-55

Máté Á., "Névetimológia és növényhatározó egy 17. századi nászénekben: jókívánságok David Spillenberger lőcsei orvos és Susanna Regina Reuther esküvőjére (1569)" [Etymology of names and plant taxonomy in a seventeenth-century epithalamium: well-wishes for the wedding of Löcse physician David Spillenberger and Susanna Regina Reuther (1569)], Antikvitás és Reneszánsz VI, no. 2 (2020), pp. 69-88

Máté Á., "A volterrai epithalamium-corvina: egy elvetélt házasság mementója” [The epithalamium corvina of Volterra: memento of an abolished marriage], Irodalomtörténeti Közlemények 124, no. 4 (2020), pp. 496-511

Mikó Á., "Báthory István király és a reneszánsz művészet Erdélyben (1576-1586)" [King Stephen Báthory and the Renaissance Art in Transylvania (1576-1586)], Müvészettörténeti Értesitö 37, no. 3-4 (1988), pp. 109-135

Niiranen S., "Counting Family Bonds after Death: Catherine and Isabella", in: Isabella Jagiellon, Queen of Hungary (1539 - 1559). Studies, ed. Á. Máté, T. Oborni (Budapest, 2020), pp. 131-146

Nowak-Dłużewski J., Okolicznościowa poezja polityczna w Polsce. Pierwsi królowie elekcyjni (Warszawa, 1969)

Nowicka-Jeżowa A., "Jan Zamoyski - vir bonus et vere humanus", in: Humanizm między Wschodem a Zachodem, ed. M. Baraniak, A. Świder-Pióro (Warszawa, 2019), pp. 111-138

Szász A., "Dés városvezetése 1541-1600 között" [City administration in Dés between 1541-1600], Erdélyi Múzeum 80, no. 1 (2018), pp. 57-70

Tagányi, K., Szolnok-Dobokavármegye monographiája [Monograph of county Szolnok-Doboka], t. 5 (Dés, 1901) 


\section{Griseldis Báthory, the Disobedient Bride or the Unsuccessful Taming of a Heretic Shrew}

The paper is the first attempt to examine the dynastic marriage of Griseldis Báthory with Jan Zamoyski from the young bride's point of view. I consider both the exchange of letters and the prints commemorating the wedding, published in Poland, as well as unpublished sources kept in the estates of historian Endre Veress, nowadays in Budapest (Veress Endre-hagyaték). Firstly, I analyse the cultural and political motives and possible agents behind the change of the bride's name from Krisztina to Griseldis. Secondly, I shed light on the conflict caused by the confessional difference between the newlyweds. I argue that the change of name was initiated by the Catholic and male party, Hetman Zamoyski and King Stephen Báthory, as a symbolic act to express the bride's obedience towards both her husband and her new country's role played in counter-Reformation in East-Central-Europe. Then, I examine the reactions of the Protestant and female party, i.e. Griseldis herself and her maternal grandmother. I argue that the name given to the Transylvanian bride in her new country became an eternal remembrance of negotiating political interests and confessional convictions between the two parties. These negotiations ended with a compromise, rather satisfactory to the female party: the bride changed her name, but she remained Protestant till the end in her soul.

Dr Ágnes Máté - pracownik Wydziału Filologii Klasycznej i Studiów Neołacińskich Uniwersytetu w Szeged (Węgry). Historyk literatury, specjalizuje się w literaturze starowęgierskiej, włoskiej i neołacińskiej. Interesuje się stosunkami węgiersko-włoskimi, rozwojem neołacińskiego opowiadania jako gatunku literackiego i jego przekładami w Europie, a także władczyniami jako pośredniczkami w przekazie kulturowym w Europie Środkowej.

Ágnes Máté, PhD - employee of the University of Szeged (Hungary), Department of Classical Philology and Neo-Latin Studies. She is a literary historian, specialising in Old Hungarian, Italian and neo-Latin literature. Her areas of interest are Hungarian-Italian relations, the development of the neo-Latin short story as a literary genre and its translations throughout Europe, and female rulers as agents of cultural transmission in Central-Europe.

E-mail: mate.agnes.klara@gmail.com 